\title{
Ecological aspects of metazoan endoparasites of Metynnis lippincottianus (Cope, 1870) (Characidae) from Upper Paraná River floodplain, Brazil
}

\author{
L. H. A. MOREIRA, R. M. TAKEMOTO, F. H. YAMADA, T. L. CESCHINI, G. C. PAVANELLI \\ Laboratório de Ictioparasitologia, Núcleo de Pesquisas em Limnologia, Ictiologia e Aqüicultura- Nupélia, \\ Universidade Estadual de Maringá, Maringá, Paraná, Brasil, E-mail: spykefloripa@hotmail.com
}

\begin{abstract}
Summary
We examined 44 specimens of Metynnis lippincottianus (Cope, 1870) (Characidae), collected in the Upper Paraná River floodplain, Brazil, from March 2006 to December 2007. Of the total number of fishes, $32(72.7 \%)$ were infected by at least one species of helminth (endoparasites). One digenean, Dadayus pacupeva, and four nematode species, Spinoxyuris oxydoras, Contracaecum sp. (larval stage), Procamallanus (Spirocamallanus) inopinatus and Raphidascaris (Sprentascaris) mahnerti were identified. D. pacupeva and S. oxydoras showed the highest values of prevalence, mean intensity and abundance. The typical pattern of overdispersion or aggregation was observed for all endoparasites. Dominance by D. pacupeva and $S$. oxydoras was observed in the parasite community. Positive association between $D$. pacupeva and two nematode species ( $S$. oxydoras and $P$.(S.) inopinatus) was observed, including positive and significant covariation between their abundances. These results suggest that species are coexisting without competition. There was no correlation between parasitism and sex for M. lippincottianus.
\end{abstract}

Key words: ecology; metazoan endoparasites; Metynnis lippincottianus; nematodes; digenean

\section{Introduction}

Brazil has a high fish diversity, and among this fishes an icthyoparasitology study was conducted with Metynnis lippincottianus (Cope, 1870) (Characidae), popularly called "peixe CD". According to Froese and Pauly (2008) this species is native of South America (Rodriguez \& Lewis, 1997), occurring in several Brazilian basins (Vieira, 2000; Makrakis et al., 2007; Silva et al., 2007). It has economic importance as food and it is also cultivated as an ornamental fish (Froese \& Pauly, 2008). The diet of species of the genus Metynnis is composed by vegetal pieces and sporadically by arthropods and detritus (Sazima, 1986;
Resende et al., 1997; Pereira et al., 2004; Dias et al., 2005). Intermediate trophic level organisms show, in general, high parasite richness and can act both as intermediate and definitive hosts (Holmes, 1990). Among the main factors influencing the composition of endoparasite communities, the feeding habit is the most important. The food items ingested by the fish can carry parasites (eggs, larval) that will determine the composition of the host parasite community (Poulin, 1998). The host's sex can be responsible for variation in the parasite fauna due to differences in behaviour, biology, and physiology between male and female fish (Machado et al., 1994; Takemoto et al., 1996). This paper aims to provide information on the endoparasites of M. lippincottianus from the Upper Paraná River floodplain, Brazil, and the influence of the host's sex in parasitism.

\section{Material and Methods}

Forty-four specimens of $M$. lippincottianus were collected, between March 2006 and December 2007, in the Upper Paraná River floodplain (22 $43^{`} \mathrm{~S}$ and $\left.53^{\circ} 10^{`} \mathrm{~W}\right)$, Brazil. Fish were captured using gill nets in several sites of the floodplain: the lakes Pau Véio, Garças and Fechada and the Baia River (Fig. 1). The sex of each fish was registered, and the internal organs and visceral cavity were analyzed under stereomicroscope. The collected parasites were treated according to Eiras et al. (2006) and identified based on Travassos et al. (1969), Yamaguti (1971) and Moravec (1998).

Statistical analysis were applied to parasites species with over $10 \%$ of prevalence and the results were considered significant when $\mathrm{p} \leq 0.05$. The ecological terms were suggested by Bush et al. (1997).

Data analysis were made using the following ecological indexes and statistical tests: the Dispersion index, tested using "d" statistics in accordance with Ludwig and Rey- 




Fig. 1. Sampling stations of Metynnis lippincottianus in the Upper Paraná River floodplain, located between the States of Mato Grosso do Sul and Paraná, Brazil

nolds (1988), to verify the dispersion pattern of the species of parasites in the sample of hosts; the degree of overdispersion or aggregation was calculated using Green's index (Ludwig \& Reynolds, 1988); Simpson's index (C) to determine dominance trends among the species of parasites, dominance being accepted when $\mathrm{C}>0.25$ (Stone \& Pence, 1978); Chi-square test $\left(\chi^{2}\right)$ to determine the occurrence of associations between species of parasites and Spearman's rank correlation (rs) to verify correlations between abundances of the species of parasites that formed associations (Ludwig \& Reynolds, 1988); "G” log likelihood test (using the $2 \times 2$ contingency table) and Mann-Whitney's test (U), used to determine effects of the host's sex in the prevalence and abundance of each species of parasite, respectively (Zar, 1996). Brillouin's index (H) was used to determine the infracommunity diversity and influence of the host's sex by using Mann-Whitney's test. Kruskal-Wallis test was used to verify the variation of parasite abundance with the environment where hosts were collected (Ayres et al., 2000).

\section{Results and Discussion}

Specific composition of the metazoan endoparasites

Five species of helminth endoparasites were found parasitizing M. lippincottianus. One digenean, Dadayus pacupeva Lacerda, Takemoto and Pavanelli, 2003; and four nematode species, Spinoxyuris oxydoras Petter, 1994; Contracaecum sp. Railliet and Henry, 1912 (larval stage); Procamallanus (Spirocamallanus) inopinatus Travassos, Artigas and Pereira, 1928 and Raphidascaris (Sprentascaris) mahnerti (Petter and Cassone, 1984) were identified. The host feeding habits determine the endoparasite community of fish (Dogiel, 1961), so probably the parasites found should use aquatic vegetation (main food) to infect $M$. lippincottianus. The fish occupies an initial position in the food web, being consumed by several animals, including man. Contracaecum sp. uses the fish as intermediate host to reach higher trophic levels, possibly composed by waterfowls, mammals and piscivorous fishes. Thus, this host, such as other fishes, is important to Contracaecum in the completion of its life cycle. The other four parasites use $M$. 
lippincottianus as definitive host, reaching their adult form. Spinoxyuris oxydoras, $P$. (S.) inopinatus and $R$. (S.) mahnerti are generalists nematodes and have being identified parasitizing several hosts (Moravec, 1998).

Structure of the community of metazoan endoparasites Of the 44 hosts examined, $32(72.7 \%)$ were infected by at least one species of helminth endoparasite. Dadayus pacupeva and $S$. oxydoras showed the highest values of prevalence, mean intensity and abundance. The values for all species are in Table 1. kind of distribution (Dobson, 1990). Aggregation can be a life strategy of the parasite to maximize its fitness, enabling largest gathering of specimens by reproduction (Holmes, 1990) or due to aggregate distribution of parasites in the environment or to the heterogenic physiology of the hosts (Poulin, 1998).

The parasites D. pacupeva and S.oxydoras (the most prevalent) showed dominance $(\mathrm{C}=0.2967)$ in the community. Thus these two parasites presented the highest values of prevalence, mean abundance and mean intensity, occurring in more than $60 \%$ of the analyzed fish, and conse-

Table 1. Number of Specimens (N), Prevalence (P), Mean Abundance (MA), Mean Intensity (MI) and Amplitude (A) of the helminth species in M. lippincottianus (Cope, 1870) from the Upper Paraná River floodplain, Paraná State, Brazil

\begin{tabular}{lccccc}
\hline Parasite species & N & P(\%) & MA & MI & A \\
\hline $\begin{array}{l}\text { Digenea } \\
\text { Dadayus pacupeva }\end{array}$ & 3568 & 61.4 & 81.1 & 132.1 & $1-575$ \\
Nematoda & & & & & \\
Spinoxyuris oxydoras & 2879 & 63.6 & 65.4 & 102.8 & $1-479$ \\
Procamallanus (Spirocamallanus) inopinatus & 44 & 43.2 & 1.00 & 2.3 & $1-9$ \\
Raphidascaris (Sprentascaris) mahnerti & 1 & 2.3 & 0.02 & 1.0 & - \\
Contracaecum sp. (larval) & 8 & 11.4 & 0.18 & 1.6 & $1-4$ \\
\hline
\end{tabular}

According to Green's index of aggregation and the Dispersion index the endoparasites D. pacupeva $(\mathrm{GI}=0.0585$; DI $=209.9 ; \mathrm{d}=124.1)$, S. oxydoras $(\mathrm{GI}=0.0514 ; \mathrm{DI}=148.9$; $\mathrm{d}=104.8), P .(S$.$) inopinatus (\mathrm{GI}=0.0438 ; \mathrm{DI}=2.9 ; \mathrm{d}=$ $6.5)$ and Contracaecum sp. $(\mathrm{GI}=0.1960 ; \mathrm{DI}=2.3 ; \mathrm{d}=$ 5.0) showed the typical pattern of overdispersion or aggregation of the parasite population. Several fish species of the Upper Paraná River floodplain (Machado et al., 1996; Machado et al., 2000; Guidelli et al., 2003; Lacerda, 2007) showed this overdispersion pattern in their parasite community, usually parasites less pathogenic show this quently, dominating the parasite community of $M$. lippincottianus. Positive association between $D$. pacupeva and two nematode species (S. oxydoras and $P$.(S.) inopinatus) was observed, as well as positive and significant covariation between their abundances (Table 2). These results suggest that the species are coexisting without competition, probably there is space and food enough in the fish for the development of all species (same ecological requirements) (Guidelli et al., 2006; Lizama et al., 2006; Karvonen et al., 2007).

Table 2. Association of endoparasite species of Metynnis lippincottianus (Cope, 1870) collected in the Upper Paraná River floodplain, Paraná State, Brazil. $\left(\chi^{2}=\right.$ Chi-square for associations of pairs of species, $r s=$ Spearman's rank correlation of species abundance of each pair $)$

\begin{tabular}{lccccc}
\hline Parasite species & $\mathbf{1}$ & $\mathbf{2}$ & $\mathbf{3}$ & $\mathbf{4}$ \\
“6rs" & \\
\hline Dadayus pacupeva (1) & & & "rs & \\
Spinoxyuris oxydoras (2) & $\#$ & $0.87 *$ & $0.30 *$ & 0.15 \\
Procamallanus (Spirocamallanus) inopinatus (3) & $(+)$ & $(+)$ & $\#$ & -0.02 \\
& $35.97 *$ & $\#$ & $0.37 *$ & -0.001 \\
Contracaecum sp. (larval) (4) & $(+)$ & $(+)$ & $(-)$ & \\
\multicolumn{1}{c}{$*$ significant values } & 1.95 & 1.69 & 0.05 & $\#$ \\
\hline
\end{tabular}


Table 3. Values of the "G" log likelihood test and Mann-Whitney's test (U), used to determine effects of the host's sex on the prevalence and abundance of each species of parasite in Metynnis lippincotianus from the Upper Paraná River floodplain, Paraná State, Brazil, respectively $(\mathrm{Z}(\mathrm{U})=$ normal approximation, $\mathrm{p}=$ significance level)

\begin{tabular}{lcccc}
\hline Parasite species & $\mathbf{G}$ & $\mathbf{P}$ & $\mathbf{Z}(\mathbf{U})$ & $\mathbf{P}$ \\
\hline $\begin{array}{l}\text { Dadayus pacupeva } \\
\text { Spinoxyuris oxydoras }\end{array}$ & 0.015 & 0.902 & 0.589 & 0.556 \\
Procamallanus (Spirocamallanus) inopinatus & - & - & 1.768 & 0.077 \\
Contracaecum sp. (larval) & 0.089 & 0.766 & 0.206 & 0.837 \\
\hline
\end{tabular}

Host's sex influence

Among the analyzed fish specimens, four were male and three $(75 \%)$ of them were parasitized by at least one species of parasite. Twenty-one out of 27 analyzed female were parasitized by at least one species of parasite, resulting in prevalence of $77.8 \%$. Thirteen out of 44 hosts collected could not have their sex determined. According to the values obtained from the " $G$ " log likelihood test and Mann-Whitney's test, the host's sex did not influence the prevalence and abundance of parasite infection, respectively (Table 3). Although the sex of the host may be an important factor influencing the levels of parasitism in the fish, due to behavioural and physiological (hormones, mucus) differences (Paling, 1965; Esch et al., 1988; Moser \& Hsieh, 1992), it did not happen in M. lippincottianus. Possibly similar diets and reproductive strategies (without parental care or lack of migration) between males and females (Hahn et al., 2004; Suzuki et al., 2004) resulted in the same parasitism levels. Previous studies with the fishes Pseudoplatystoma corruscans (Machado et al., 1994), Paulicea luetkeni (=Zungaro zungaro) (Takemoto \& Pavanelli, 1994) and Prochilodus lineatus (Lizama et al., 2005) in the Upper Paraná River floodplain, did not show influence of the host's sex on parasitism, such as the present work. The independence of prevalence and abundance in relation to the sex of $M$. lippincottianus can constitute evidence that the diet and distribution in the environment (ecological relationships) are similar between males and females.

There were no statistical significant differences $(\mathrm{Z}(\mathrm{U})=$ 0.47 and $p=0.6374$ ) of the endoparasite diversity between males and females, mean Brilouin index 0.4318 and 0.4130 , respectively. Probably this fact is due to the behaviour and other features (ecological relationships) similar in males and females, discussed previously. As the fish were collected using gillnets, we could not have an equal division between the sexes, resulting in larger number of females and few males (only four). Perhaps this sampling problem might have influenced the results.

Influence of the environments on the abundance of parasites in the Upper Paraná River floodplain

Dadayus pacupeva $(\mathrm{H}=23.623 ; \mathrm{p}<0.0001)$ and $S$. oxydoras $(\mathrm{H}=22.449 ; \mathrm{p}=0.0001)$ showed significant statistical differences in abundance according to the collection site, but not for P.(S.) inopinatus and Contracaecum sp. Dadayus pacupeva was not found in the Pau Véio Lake and had the highest mean abundance in the Baia River (Mean Abundance $=185.86$ ). Spinoxyuris oxydoras was not found in the Pau Véio Lake and the highest abundance in the Fechada Lake (Mean Abundance $=102.000$ (Fig. 2). Probably limnological characteristics (Pavanelli et al., 1997) or absence of intermediate hosts or vegetation (used as food) (Pereira et al., 2004; Dias et al., 2005) resulted in

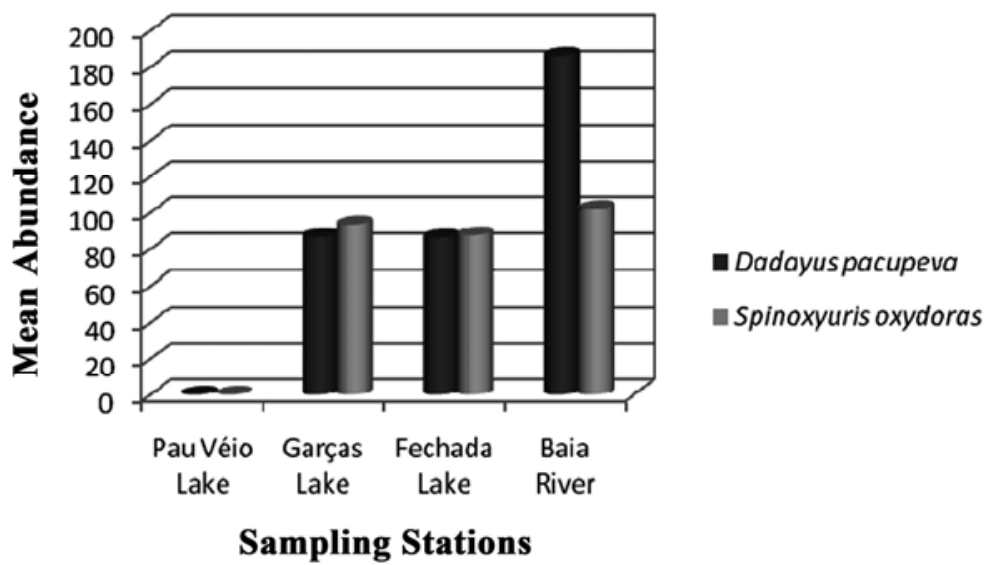

Fig. 2. Mean Abundance of Dadayus pacupeva and S. oxydoras collected in Pau Véio Lake, Garças Lake, Fechada Lake and Baia River, environments of Upper Paraná River floodplain 
the absence of these parasites in the Pau Véio Lake. On the other hand, there must be favourable factors allowing the life cycle of the digenean (intermediate hosts) and nematodes (vegetation) (Sazima, 1986; Resende et al., 1997) in the Baia River and the Fechada Lake, respectively. Probably the absence of correlation between P.(S.) inopinatus and Contracaecum sp. is because their possible intermediate hosts, chironomids and microcrustaceans, respectively, are present in all studied sites.

\section{References}

Ayres, M., Ayres, Jr. M., Ayres, D. L., Santos, A. S. (2000): BioEstat 2.0: Aplicações estatísticas nas áreas de ciências biológicas e médicas. Belém: Sociedade Civil Mamirauá; Brasília, D. F.: CNPq, 272pp.

Bush, A. O., Lafferty, K. D., Lotz, J. M., Shostak, A. W. (1997): Parasitology meets ecology on its own terms: Margolis et al. Revisited. J. Parasitol., 83(4): 575 - 583

Dias, A. C. M. I., Branco, C. W. C., Lopes, V. G. (2005): Estudo da dieta natural de espécies de peixes no Reservatório de Riberão das Lajes, RJ. Acta Sci., 27(4): 355 364

DoBson, A. P. (1990): Models of multi-species parasiteshost communities. In: EsCH, G. W. Bush, A. O., AHO, J. (Eds) Parasite communities: patterns and process. New York: Chapman and Hall, pp. $261-288$

DoGiEL, V. A. (1961): Ecology of the parasites of freshwater fishes. In: Dogiel, V. A. Petrushevski, G. K., POLYANSKI, YU. I. (Eds) Parasitology of Fishes. London: Olivier \& Boyd, pp. $1-47$

Eiras, J. C., TAKemoto, R. M., Pavanelli, G. C. (2006): Métodos de Estudo e Técnicas Laboratoriais em Parasitologia de Peixes. Maringá: EDUEM, 199 pp.

Esch, G. W. Kennedy, C. R., Bush, A. O., Aho, J. M. (1988): Patterns in helminth communities in freshwater fish in Great Britain: alternative strategies for colonization. Parasitology, 96: 519 - 532

Froese, R., PAuly, D. (Eds) FishBase - World Wide Web electronic publication version (12/2008), Taipei, Taiwan. Retrieved December 12, 2008 rom http://www.fishbase.org /search.php

Guidelli, G. M. ISAAC, A., TAKEMOTO, R. M., PAVANELli, G. C. (2003): Endoparasite infracommunities of Hemisorubim platyrhynchos (Valenciennes, 1840) (Pisces: Pimelodidae) of the Baía River, Upper Paraná River floodplain, Brazil: specific composition and ecological aspects. Braz. J. Biol., 63(2): $261-268$

Guidelli, G. M., Tavechio, W. L. G., Takemoto, R. M., PaVAnelli, G. C. (2006): Fauna parasitária de Leporinus lacustris e Leporinus friderici (Characiformes, Anostomidae) da planície de inundação do alto rio Paraná, Brasil. Acta Sci., 28(3), $281-290$

Hahn, N. S., Fugi, R., Lourero-Crippa, V. E., Peretti, D., Russo, M. R. (2004): Trophic structure of the fish fauna. In: Agostinho, A. A., Rodrigues, L., Gomes, L. C., Thomaz, S. M., Miranda, L. E. (Org.). Structure and functioning of the Paraná River and its floodplain: (PELD -
Site 6). Maringá: EDUEM, pp. 139 - 143

Holmes, J. C. (1990): Competition, contacts, and other factors restricting niches of parasitic helminths. Ann. Parasitol., 65: $69-72$

Karvonen, A., Bagge, A. M., Valtonen, E. T. (2007): Interspecific and intraspecific interactions in the monogenean communities of fish: a question of study scale? Parasitology, 134: $1237-1242$

LACERDA, A. C. F. (2007): Endoparasitos de raias fluviais Potamotrygon falkneri e Potamotrygon motoro (Chondrichthyes: Potamotrygonidae) na planície de inundação do alto rio Paraná: Taxonomia e aspectos ecológicos. Msc thesis, Brazil, Maringá: Universidade Estadual de Maringá. Lizama, M. A. P., Takemoto, R. M., Pavanelli, G. C. (2005): Influence of host sex and age on infracommunities of metazoan parasites of Prochilodus lineatus (Valenciennes, 1836) (Prochilodontidae) of the Upper Paraná River floodplain, Brazil. Parasite, 12(4): 299 - 304

Lizama, M. A. P., Takemoto, R. M., Pavanelli, G. C. (2006): Parasitism influence on the hepato, splenossomatic and weight/length relation factor of Prochilodus lineatus (Valenciennes, 1836) (Prochilodontidae) of the upper Paraná river floodplain, Brazil. Rev. Bras. Parasitol. Vet., 15(3): $116-122$

Ludwig, J. A., REYnOlds, J. F. (1988): Statistical Ecology: a Primer on Methods and Computing. New York: Wiley-Interscience Publications, 179 pp.

Machado, M. H., Pavanelli, G. C., Takemoto, R. M. (1994): Influence of host's sex and size on endoparasitic infrapopulations of Pseudoplatystoma corruscans and Schizodon borelli (Osteichthyes) of the High Paraná River, Brazil. Rev. Bras. Parasitol. Vet., 3(2): 143 - 148

Machado, M. H., Pavanelli, G. C., Takemoto, R. M. (1996): Structure and diversity of endoparasitic infracommunities and the trophic level of Pseudoplatystoma corruscans and Schizodon borelli (Osteichthyes) of the High Paraná River. Mem. Inst. Oswaldo Cruz, 91(4): 441 - 448 Machado, P. M., Almeida, S. C., Pavanelli, G. C., TAKEMOTO, R. M. (2000): Ecological aspects of endohelminths parasitizing Cichla monoculus Spix, 1831 (Perciformes: Cichlidae) in the Paraná River near Porto Rico, State of Paraná, Brazil. Comp. Parasitol., 67(2): 210 - 217 Makrakis, S., Gomes, L. C., MaKraKIS, M. C., Fernandez, D. R., PAVAnelli, C. S. (2007): The Canal da Piracema at Itaipu Dam as a fish pass system. Neotrop. Ichthyol., 5(2): 185 - 195

MoRAVEC, F. (1998): Nematodes of freshwater fishes of the neotropical region. Prague: Academia, 464pp.

Moser, M., HsIEH, J. (1992): Biological tags for stock separation in Pacific herring Clupea harengus pallasi in California. J. Parasitol., 78(1): $54-60$

Pavanelli, G. C., Machado, M. H., Takemoto, R. M. (1997): Fauna helmíntica de peixes do rio Paraná, região de Porto Rico, Paraná. In: Vazzoler, A. E. A. M., Agostinho, A. A., HAhn, N. S. (Eds). A planície de inundação do alto rio Paraná: aspectos físicos, biológicos e socioeconômicos. Maringá: Eduem, pp. 307-329.

PAling, J. E. (1965): The population dynamics of the 
monogenean gill. parasite Discocotyle sagittata Leuckart on Windermere trout, Salmo trutta. L. Parasitology, 55(4): $667-694$

Pereira, C. C. G. F. Smith, W. S., Espindola, E. L. G. (2004): Hábitos alimentícios de nueve espécies de peces Del embalse de Três Irmãos, São Paulo, Brazil. Universidad Ciencia, 1: 33 - 38

Poulin, R. (1998): Evolucionary ecology of parasites: from individuals to communities. London: Chapman \& Hall, 728pp.

Resende, E. K., Pereira, R., Almeida, V. L. (1997): Peixes herbívoros da planície inundável do rio Miranda, Mato Grosso do Sul, Brasil. CPAP - Boletim de Pesquisa EMBRAPA, 10: 1 - 21

RodriguEZ, M. A., LEWIS, W. M. (1997): Structure of fish assemblages along environmental gradients in floodplain lakes of the Orinoco River. Ecol. Monogr., 67(1): $109-$ 128

SAZIMA, I. (1986): Similarities in feeding behavior between some marine and freshwater fishes in two tropical communities. J. Fish Biol., 29(1): $53-65$

Silva, E.F., Melo, C. E., Venêre, P. C. (2007): Fatores que influenciam a comunidade de peixes em dois ambientes no baixo Rio das Mortes, Planície do Bananal, Mato Grosso, Brasil. Rev. Bras. Zool., 24(2): 482-492.

Stone, J. E., Pence, D. B. (1978): Ecology of helminth parasitism in the bobcat from West Texas. J. Parasitol., 64
(2): $295-302$

Suzuki, H. I., Pelicice, F. M., Luiz, E. A., Latini, J. D., Agostinho, A. A. (2004): Reproductive strategies of the fish community of the Upper Paraná river floodplain. In: Agostinho, A. A., Rodrigues, L., Gomes, L. C., ThOMAZ, S. M., MiRANDA L. E.(Org.). Structure and functioning of the Paraná River and its floodplain. Maringá EDUEM, pp. 125 - 130

TAkemoto, R. M. Amato, J. F. R., Luque, J. L. (1996): Comparative analysis of the metazoan parasite communities of leatherjackets, Oligoplites palometa, O. saurus, and O. saliens (Osteichthyes: Carangidae) from Sepetiba Bay, Rio de Janeiro, Brazil. Braz. J. Biol., 56(4): $639-650$

TAkemoto, R. M., PAVAnelli, G. C. (1994): Ecological aspects of proteocephalidean cestodes parasites of Paulicea luetkeni (Steindachner) (Osteichthyes: Pimelodidae) from the Paraná, Brazil. Revista UNIMAR, 16(3): 17 - 26 Travassos, L., Freitas, J. F. T., Kohn, A. (1969): Trematódeos do Brasil. Memórias do Instituto Oswaldo Cruz, 67(1): 886pp.

VIEIRA, I. (2000): Freqüência,constância, riqueza e similaridade da ictiofauna da bacia do rio Curuá-Una, Amazônia. Revista Brasileira de Zoociências, 2(2): 51-76. YAMAGUTI, S. (1971): Synopsis of digenetic trematodes of vertebrates. Tokyo: Keigaku Publishing, vol. 1, 1074pp.

ZAR, J. H. (1996): Biostatistical Analysis. New Jersey: Prentice-Hall International Editions, 662 pp. 